\title{
Human plasma fractions inhibit the action of insulin on adipocytes and somatomedin on cartilage
}

\author{
N. Avasthy, M. A. Khokher, A. M. Taylor and P. Dandona \\ Metabolic Unit, Department of Chemical Pathology and Human Metabolism, Royal Free Hospital and School of Medicine, London, UK
}

Summary. Since human immunoglobulins exert an insulinlike stimulatory effect on adipocyte lipogenesis at concentrations markedly lower than those found in vivo, and since human serum or plasma are only mildly stimulatory, we predicted that human serum probably contains an inhibitor of adipocyte lipogenesis. Supernatant preparations, obtained from the precipitation of immunoglobulins from plasma in $2.5 \mathrm{~mol} / 1$ ammonium sulphate, were extensively dialysed and tested for their activity on bioassay systems commonly used for measuring insulin. The supernatants produced a marked inhibition of basal and insulin- or IgG-stimulated lipogenesis and glucose oxidation by adipocytes at protein concentrations of $10 \mathrm{mg} / 1$. The supernatants were further purified through ul- trafiltration to demonstrate two main inhibitory fractions, 10 to $30 \mathrm{~K}$ and 30 to $50 \mathrm{~K}$, which again produced marked inhibition of basal and insulin- or IgG-stimulated adipocyte lipogenesis and glucose oxidation. These fractions were then tested for basal and serum somatomedin-stimulated ${ }^{35} \mathrm{~S}$ sulphate uptake by porcine cartilage: both basal and serum somatomedin-stimulated ${ }^{35} \mathrm{~S}$ uptake were significantly inhibited $(p<$ 0.01 ). Therefore, normal human serum contains at least two peptides which are markedly inhibitory to glucose metabolism and insulin action on adipocytes and ${ }^{35} \mathrm{~S}$ transport and somatomedin action on cartilage.

Key words: Insulin inhibitors, somatomedin inhibitors.
We have recently demonstrated that human immunoglobulins IgG [1] and IgM [2] exert an insulin-like stimulatory effect upon lipogenesis and glucose oxidation by rat and human [3] adipocytes. This effect is mediated through the Fc moiety [3, 4] of the IgG molecule, and is not neutralised by anti-insulin antisera. This effect of $\mathrm{Ig}$ must therefore contribute to the non-suppressible insulin-like activity of serum/plasma. In fact, we have observed that serum non-suppressible insulin-like activity attributable to a high molecular weight fraction (NSILP) may be antigenically similar to IgG [5]. Since this potent stimulatory effect of immunoglobulins is exerted at very low concentrations when compared with those present in plasma, and since plasma itself has only a marginal stimulatory effect upon adipocyte metabolism, we postulated the presence in plasma of an inhibitor of immunoglobulin stimulated adipocyte lipogenesis $[1,3]$. Our preliminary observations did, indeed, reveal the presence of such an inhibitor [1]. We have now expanded our investigations to attempt to define the nature of this inhibitor. The experiments described in this paper show that there are probably two inhibitors in human plasma which are active not only against the stimulatory effect of insulin and immunoglobulins on adipocytes, but also on that of serum somatomedin on ${ }^{35} \mathrm{~S}$ uptake by cartilage.

\section{Materials and methods}

Analytical grade sodium chloride, sodium hydroxide, sodium hydrogen carbonate, potassium chloride, calcium chloride, sodium dihy- drogen phosphate, glucose, triton X-100 (scintillation grade), toluene, hyamine-10x hydroxide (scintillation grade), methanol and sulphuric acid were obtained from British Drug House (BDH, Enfield, UK). D$\left[3-{ }^{3} \mathrm{H}\right]$ glucose and $\mathrm{D}-\left[\mathrm{U}-{ }^{14} \mathrm{C}\right]$ glucose were obtained from Amersham International (Amersham, UK). Bovine serum albumin fraction $V$ was obtained from Armour Pharmaceuticals (Eastbourne, UK). Collagenase from clostridium histolycum (specific activity $131 \mathrm{U} / \mathrm{mg}$ ) was obtained from Millipore Corporation (Bedford, NJ, USA). Epididymal fat pads were obtained from caesarian-delivered male SpragueDawley rats, weighing $100-180 \mathrm{~g}$ and kept on an ad libitum diet (Grain Harvesters Brand 41B). Amicon ultrafiltration membranes were obtained from Amicon Limited (Stonehouse, Glous., UK).

Costal cartilage was removed from the sternal ends of the lowest ribs of freshly killed pigs in an abattoir and transported in isotonic saline $\left(4^{\circ} \mathrm{C}\right)$ to the laboratory. Discs were cut from the cartilage and used in the somatomedin bioassay the same afternoon.

\section{Preparation of the inhibitory fraction from serum}

Supernatants were obtained from normal human serum by precipitation of serum globulins in $2.5 \mathrm{~mol} / 1$ ammonium sulphate followed by 10 -min centrifugation at $1500 \mathrm{~g}$. The supernatants were dialysed extensively for $72 \mathrm{~h}$ against water. The protein content of dialysed supernatants was then measured by the method of Lowry et al. [6]. These fractions were assayed for their inhibitory activity on adipocyte lipogenesis and $\left[{ }^{14} \mathrm{Cl}\right.$-glucose oxidation to $\mathrm{CO}_{2}$ as described below.

Further fractionation of these supernatant preparations was carried out through sequential filtration on ultrafiltration membranes (Amicon) with nominal molecular weight cut-offs: - 1, 5, 10, 30, 50, 100 , and $500 \mathrm{~K}$.

Each fraction thus obtained was assayed for its action on adipocytes and ${ }^{35} \mathrm{~S}$ uptake by cartilage. Initial preparatory experiments were carried out at room temperature, but later it was found that there was some loss of biological activity of these inhibitor fractions at room temperature. Further preparatory work was carried out at $4{ }^{\circ} \mathrm{C}$.

The biological activity of these supernatant preparations was tested in the following biological systems: (1) adipocyte lipogenesis; (2) 
Table 1. The effect of serum inhibitor on rat adipocyte lipogenesis in the presence of either insulin or IgG

\begin{tabular}{|c|c|c|c|c|c|}
\hline $\begin{array}{l}\text { Insulin } \\
\text { concentration } \\
\mathrm{mU} / 1\end{array}$ & Insulin alone & $\begin{array}{l}\text { Insulin + inhibitor } \\
10 \mathrm{mg} / \mathrm{l}\end{array}$ & $\begin{array}{l}\text { IgG concentration } \\
\mathrm{mg} / 1\end{array}$ & IgG alone & $\begin{array}{l}\operatorname{IgG}+\text { inhibitor } \\
10 \mathrm{mg} / 1\end{array}$ \\
\hline 0 & 100 & $75 \pm 8^{\mathrm{a}}$ & 0 & 100 & $41 \pm 5^{\mathrm{a}}$ \\
\hline 5 & $215 \pm 44$ & $196 \pm 7$ & 50 & $152 \pm 8$ & $44 \pm 5^{b}$ \\
\hline 10 & $500 \pm 28$ & $200 \pm 8^{b}$ & 100 & $182 \pm 10$ & $75 \pm 8^{b}$ \\
\hline 20 & $1054 \pm 40$ & $360 \pm 12^{b}$ & 200 & $817 \pm 13$ & $163 \pm 4^{b}$ \\
\hline
\end{tabular}

Results are expressed as percentage stimulation over basal \pm SEM. Basal counts: $257 \mathrm{cpm}(=100 \%)$; non-specific background counts: $87 \mathrm{cpm}$; $n=6$. ${ }^{a} p<0.01$ when compared with basals; ${ }^{\mathrm{b}} p<0.01$ when compared with the corresponding dose of insulin or IgG

glucose oxidation to $\mathrm{CO}_{2}$ by adipocytes; and (3) ${ }^{35} \mathrm{~S}$-sulphate uptake by porcine cartilage. In the first two systems, the effect of the inhibitor fraction was tested against the basal and insulin-stimulated activity. In system (3), the effect of the inhibitor was tested against basal and serum somatomedin-stimulated activity.

\section{Studies on rat adipocytes}

Rat adipocytes were prepared from epididymal fat pads by collagenase digestion in Krebs-Ringer bicarbonate buffer, $\mathrm{pH} 7.4$, containing 1\% albumin [7]. The cells were gently but extensively washed and resuspended in the same buffer. Adipocyte lipogenesis was assayed by the method described by Moody et al. [8] as adapted by us [9]. $\left[\mathrm{U}-{ }^{14} \mathrm{C}\right.$-glucose oxidation to $\left[{ }^{14} \mathrm{C}\right]-\mathrm{CO}_{2}$ was measured as described by us previously [10]. All incubations with insulin-inhibitory fractions, with and without insulin, were carried out by incubating the fractions with adipocytes for the entire incubation period of $120 \mathrm{~min}$.

The effect of heat treatment on inhibitor preparations was assessed by incubating these preparations for $20 \mathrm{~min}$ at $60^{\circ} \mathrm{C}$ and $80^{\circ} \mathrm{C}$ respectively in a shaking water bath. These treated preparations were assayed by the rat lipogenesis bioassay.

\section{Porcine cartilage ${ }^{35}$ S-sulphate uptake}

The effect of the supernatants on ${ }^{35} \mathrm{~S}$-sulphate uptake by porcine cartilage was tested in the presence and absence of serum somatomedin activity as described by Spencer and Taylor [11] and as used to test the effect of other agents on this system [12]. All incubations of cartilage with inhibitory fractions were carried out for the entire incubation period of $24 \mathrm{~h}$, as previously described [11].

\section{Statistical analysis and expression of results}

Results were analysed using paired Student's t-tests (two-tailed), and are all expressed as \% change over basal $(100 \%)$.

The absolute basal counts per minute are shown with each Table and Figure. A minimum of 4 experiments was carried out for each Table or Figure shown. Each Table or Figure shows the results obtained from one experiment only so that the values shown are directly comparable.

\section{Results}

Supernatants obtained following ammonium sulphate precipitation of serum and prolonged dialysis against water caused a marked inhibition of basal and insulinstimulated lipogenesis. A similar inhibition of $\left[\mathrm{U}_{-}{ }^{14} \mathrm{C}\right]-$ glucose oxidation to $\left[{ }^{14} \mathrm{Cl}-\mathrm{CO}_{2}\right.$ was observed. Heat treatment of the supernatant decreased the inhibitory activity observed over basal and insulin-stimulated lipogenesis. This preparation was not tested for its effect on ${ }^{35} \mathrm{~S}$-sulphate uptake by cartilage.
Table 2. Effect of serum inhibitor on the oxidation of [U- $\left.{ }^{14} \mathrm{C}\right]$-glucose to $\left[{ }^{14} \mathrm{C}\right]-\mathrm{CO}_{2}$ by rat adipocytes

\begin{tabular}{ll}
\hline Test & Percentage stimulation + SEM \\
\hline Insulin alone & $153 \pm 11$ \\
$5 \mathrm{mU} / 1$ & $161 \pm 28$ \\
$10 \mathrm{mU} / 1$ & $177 \pm 5$ \\
$20 \mathrm{mU} / 1$ & \\
Serum inhibitor alone & $55 \pm 7^{\mathrm{a}}$ \\
$1 \mathrm{mg} / \mathrm{l}$ & $19 \pm 5^{\mathrm{a}}$ \\
$2 \mathrm{mg} / \mathrm{l}$ & \\
Serum inhibitor $+10 \mathrm{mUl}^{-1}$ insulin & \\
$1 \mathrm{mg} / 1+10 \mathrm{mU} / 1$ insulin & $18 \pm 28^{\mathrm{b}}$ \\
$2 \mathrm{mg} / 1+10 \mathrm{mU} / 1$ insulin & $4^{\mathrm{b}}$ \\
\hline a $p<0.01$ when compared with controls; ${ }^{\mathrm{b}} p<0.001$ when com- \\
pared with response to $10 \mathrm{~m} U / 1$ insulin \\
Results are expressed as \% change over basal. Basal counts: $340 \mathrm{cpm}$ \\
(=100\%). Non-specific background counts: $45 \mathrm{cpm} . n=6$
\end{tabular}

Table 3. Effect of heat treatment on serum inhibitor activity in basal and insulin-stimulated lipogenesis.

\begin{tabular}{llcll}
\hline $\begin{array}{l}\text { Insulin } \\
\text { concentration } \\
(\mathrm{mU} / 1)\end{array}$ & $\begin{array}{l}\text { Insulin } \\
\text { alone }\end{array}$ & $\begin{array}{l}\text { Insulin }+ \text { se- } \\
\text { rum inhibitor } \\
(1 \mathrm{mg} / 1)\end{array}$ & $\begin{array}{l}\text { Insulin }+ \text { se- } \\
\text { rum inhibitor } \\
\left(60^{\circ} \mathrm{C}\right)\end{array}$ & $\begin{array}{l}\text { Insulin+ } \\
\text { serum in- } \\
\text { hibitor } \\
\left(80^{\circ} \mathrm{C}\right)\end{array}$ \\
\hline 0 & 100 & 0 & $91 \pm 21$ & - \\
5 & $188 \pm 53$ & $108 \pm 70$ & $114 \pm 71$ & $242 \pm 45$ \\
10 & $222 \pm 70$ & $102 \pm 16$ & $191 \pm 19$ & $267 \pm 54$
\end{tabular}

Results are expressed as percentage stimulation over basal \pm SEM. Basal counts: $80 \mathrm{cpm}(=100 \%) ; n=5$

Further purification of the inhibitor using ultrafiltration membranes showed that two major molecular fractions, $10-30 \mathrm{~K}$ and $30-50 \mathrm{~K}$ were markedly inhibitory to adipocyte lipogenesis. Minimal inhibition was also observed with a fraction of $<10 \mathrm{~K}$ (data not shown). Fractions of $>50 \mathrm{~K}$ were consistently stimulatory in the adipocyte lipogenesis assay (data not shown).

Each of the fractions inhibitory in the adipocyte assays, $10-30 \mathrm{~K}$ and $30-50 \mathrm{~K}$, were also assayed for their action on ${ }^{35} \mathrm{~S}$-sulphate uptake by porcine cartilage. Both fractions inhibited the basal and serum stimulated ${ }^{35} \mathrm{~S}$ uptake by cartilage markedly in a dose-related fashion (Figs. 1, 2).

Incubation of the crude inhibitory fraction at $60^{\circ} \mathrm{C}$ resulted in over $75 \%$ loss of inhibitory activity whilst that at $80^{\circ} \mathrm{C}$ resulted in its total loss. 
Table 4. Inhibition of basal and insulin stimulated-lipogenesis in rat adipocytes by serum inhibitor fractions 10 - 30 kilodaltons (A) and 30-50 kilodaltons (B)

\begin{tabular}{lll}
\hline Test & $\begin{array}{l}\text { A } \\
\text { Percentage stimu- } \\
\text { lation + SEM } \\
\text { (basal counts: } \\
270 \mathrm{cpm}=100 \%)\end{array}$ & $\begin{array}{l}\text { B } \\
\text { Percentage stimu- } \\
\text { lation + SEM } \\
\text { (basal counts: }\end{array}$ \\
& $\begin{array}{l}250 \mathrm{cpm}=100 \%) \\
n=6\end{array}$ \\
\hline Insulin & \\
$1.25 \mathrm{mU} / 1$ & $226 \pm 28$ & $117 \pm 16$ \\
$2.50 \mathrm{mU} / 1$ & $264 \pm 37$ & $139 \pm 7$ \\
$5.00 \mathrm{mU} / 1$ & $358 \pm 38$ & $222 \pm 19$ \\
$10.00 \mathrm{mU} / 1$ & $448 \pm 34$ & $323 \pm 16$ \\
$20.00 \mathrm{mU} / 1$ & $531 \pm 27$ & $350 \pm 25$ \\
Fractions & & \\
$0.5 \mathrm{mg} / 1$ & $88 \pm 15$ & $62 \pm 16^{\mathrm{a}}$ \\
$1.0 \mathrm{mg} / 1$ & $72 \pm 18^{\mathrm{a}}$ & $24 \pm 2^{\mathrm{a}}$ \\
$2.0 \mathrm{mg} / 1$ & $0^{\mathrm{a}}$ & $20 \pm 4^{\mathrm{a}}$ \\
$3.0 \mathrm{mg} / 1$ & $0^{\mathrm{a}}$ & $1 \pm 3^{\mathrm{a}}$ \\
Fractions $+2.5 \mathrm{mU} / 1$ insulin & $103 \pm 13^{\mathrm{b}}$ \\
$0.5 \mathrm{mg} / 1$ & $193 \pm 17^{\mathrm{b}}$ & $69 \pm 6^{\mathrm{b}}$ \\
$1.0 \mathrm{mg} / 1$ & $84 \pm 15^{\mathrm{b}}$ & $25 \pm 5^{\mathrm{b}}$ \\
$2.0 \mathrm{mg} / 1$ & 0 & $1 \pm 3^{\mathrm{b}}$ \\
$3.0 \mathrm{mg} / 1$ & 0 &
\end{tabular}

a $p<0.01$ when compared with basal; b $p<0.01$ when compared with corresponding dose of insulin

\section{Discussion}

The data presented show a marked antagonistic effect of the inhibitor preparations on basal and insulin- or IgG-stimulated lipogenesis. A similar potent inhibitory effect was observed on the oxidation of glucose to $\mathrm{CO}_{2}$ by adipocyte suspensions. Clearly, therefore, plasma/ serum contains potent inhibitors of adipocyte metabolism; these inhibitors may have a modulatory effect upon the metabolic actions of insulin and immunoglobulins in vivo. The two active inhibitory fractions, $10-30 \mathrm{~K}$ and $30-50 \mathrm{~K}$ also inhibited ${ }^{35} \mathrm{~S}$ uptake markedly. This inhibition was evident with and without the addition of the standard human serum which has a stimulatory effect on this preparation due to its intrinsic somatomedin content.

It is noteworthy that an inhibitor of somatomedin action has previously been recognised in sera of rats rendered experimentally diabetic [13]: this inhibitor is a protein which neutralises the biological effect of nonsuppressible insulin-like activity-S (NSILA-S). It has been suggested that this protein inhibits plasma NSILA-S by binding to it. The large molecular weight of this NSILA-S binding protein complex prevents the transcapillary passage of NSILA-S and this is thought to protect the putative target tissues from an effect of NSILA-S in vivo. The inhibitory effect of this carrier protein was also observed when assessing the activity of NSILA-S in vitro; this was caused by inhibiting binding of NSILA-S to perfused rat heart. This carrier protein does not, however, inhibit the stimulatory effect of insu-

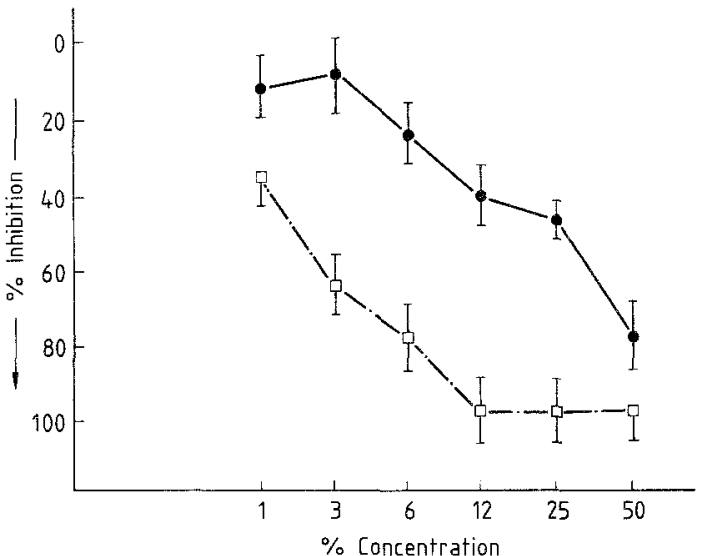

Fig. 1. The inhibitory effect of plasma fractions $10-30 \mathrm{~K}(-\mathrm{C})$ and $30-50 \mathrm{~K}(\square-\cdot-\cdot-\square)$ on ${ }^{35} \mathrm{~S}$ uptake by porcine cartilage. Serial concentrations of inhibitor used were derived from a parent solution containing $3 \mathrm{mg} / 1$ protein. Dilutions were carried out with Ham's $F_{12}$ medium. For $10-30 \mathrm{~K}$ plasma fraction assays, all values of $6 \%$ concentration and above were significantly inhibitory when compared with basal values $(p<0.01)$. For $30-50 \mathrm{~K}$ plasma fraction assays all values of $3 \%$ and above were significantly inhibitory $(p<0.01)$ when compared with basal values; $n=5$

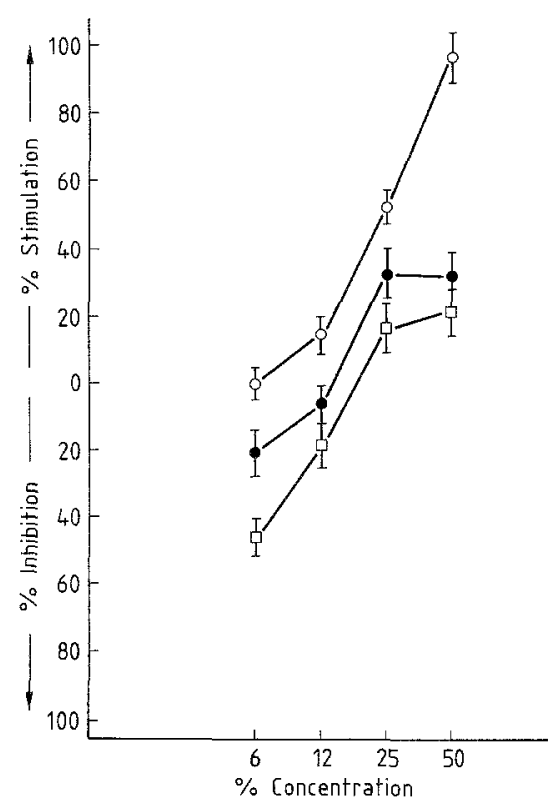

Fig. 2. The inhibitory effect of plasma fractions $10-30 \mathrm{~K}$ and $30-50 \mathrm{~K}(\square-\square)$ on ${ }^{35} \mathrm{~S}$ uptake by porcine cartilage stimulated by normal human serum $(\mathrm{O}-\mathrm{O})$. Protein concentrations of parent solutions of inhibitor fractions: $3 \mathrm{mg} / 1$. Normal human serum and inhibitory fractions were used in dilutions from $6 \%$ to $50 \%$ in Ham's $F_{12}$ medium. Four experiments were performed with 4 separate sets of inhibitory fractions. For $10-30 \mathrm{~K}$, plasma fraction assay values at 6,12 and $25 \%$ concentrations were significantly $(p<0.05)$ inhibitory, and at $50 \%$ concentration $(p<0.01)$, inhibition was also achieved when compared with normal human serum. For $30-50 \mathrm{~K}$ plasma fraction assays, the $6 \%$ concentration was significantly inhibitory $(p<0.05)$ and the 12,25 and $50 \%$ concentrations were also significantly inhibitory $(p<0.01)$ when compared with normal human serum; $n=5$

lin on myocardial glucose uptake, and exerted no effect on the binding of insulin to perfused rat heart.

In contrast to these observations, our inhibitor preparations were equally effective in inhibiting: (1) basal 
and insulin- and IgG-stimulated adipocyte metabolism and (2) basal and serum somatomedin-stimulated ${ }^{35} \mathrm{~S}$ sulphate uptake by cartilage. Therefore, it is not likely that these inhibitory fractions are specific binding proteins. No comment, however, is possible regarding the association/binding of these inhibitors to any of these stimulators in circulation. Ultrafiltration experiments show that either there are two molecular species $(10-30 \mathrm{~K}$ and $30-50 \mathrm{~K})$ of inhibitor. Whereas the two fractions are equipotent on the rat adipocyte lipogenesis assay, the higher molecular weight fraction $(30-50 \mathrm{~K})$ is more potent in the cartilage bioassay. This difference in inhibitory potency is evident against both basal and human serum-stimulated ${ }^{35} \mathrm{~S}$ uptake by cartilage (Figs. 1, 2). Phillips and co-workers [14] have recently isolated three molecular fractions from sera of diabetic rats which are inhibitory to ${ }^{35} \mathrm{~S}$ sulphate uptake by cartilage under basal conditions and following somatomedin stimulation. Whereas one of our inhibitors may be related to their $24 \mathrm{~K}$ inhibitor, their other two inhibitors of molecular weights of $250 \mathrm{~K}$ and $940 \mathrm{~K}$ are not likely to be related to the two main adipocyte/cartilage inhibitors described by us.

The inhibitors described by us inhibit both basal and insulin/IgG-stimulated adipocyte metabolism. Since insulin and IgG stimulate adipocyte metabolism through different receptors, our inhibitory fractions interfere with insulin/IgG effects on adipocytes at a postreceptor level. Furthermore, these inhibitory fractions have profound effects on two different targets organs, the adipose tissue and the cartilage. This suggests that the inhibitors may have a general toxic effect, or that they affect a key pathway involved in the mediation of hormonal effects on various tissues: more definite comments on the mechanism of action are not possible at the present stage. Our preparatory techniques indicate that these inhibitors are not fatty acids, since they were not dialysed out even after $72-96 \mathrm{~h}$ of continuous dialysis against water. The inhibitors appear to be heat labile proteins which lose over $75 \%$ of their biological activity at $60^{\circ} \mathrm{C}$ and all of it at $80^{\circ} \mathrm{C}$. These inhibitors are not related to synalbumin antagonist of insulin described by Vallance-Owen [15, 16], since (1) they are not associated with albumin on ultrafiltration (molecular weight of inhibitors is $10-50 \mathrm{~K}$, whereas that of albumin is $>70 \mathrm{~K}$ ); (2) synalbumin antagonist has no effect on adipose tissue; and (3) synalbumin antagonist is found only in sera of diabetic patients.

The biological significance of these inhibitors is not clear at present and requires further elucidation. Whether the deficiency of such inhibitors may result in hypersensitivity or hyper-responsiveness to insulin in vivo, or that their excess would result in insulin resistance, is an area which requires critical evaluation. Similarly, these inhibitors may modulate sensitivity to somatomedins and thus affect growth processes. Meuli et al. [13] have suggested that their carrier protein may be responsible for 'protecting tissues' from uncontrolled activity of NSILA; our inhibitor may be responsible for a similar effect.

\section{References}

1. Khokher MA, Dandona P, Janah S, Coulston LG (1981) Insulinlike stimulatory effect of human immunoglobulin $G$ on adipocyte lipogenesis. Diabetes 30: 1068-1071

2. Khokher MA, Woods RJ, Dandona P (1984) Human immunoglobulin $\mathrm{M}$ stimulates adipocyte lipogenesis. Metabolism 33: 208-211

3. Khokher MA, Janah S, Dandona P (1983) Human immunoglobulin $\mathrm{G}$ stimulates human adipocyte lipogenesis. Diabetologia 25: $265-268$

4. Khokher MA, Dandona $\mathbf{P}$ (1983) Insulin-like stimulatory effect of $\mathrm{F}_{\mathrm{c}}$ fragments of human immunoglobulin $\mathrm{G}$ on rat adipocyte lipogenesis: indirect evidence for $\mathrm{F}_{\mathrm{c}}$ receptor on adipocytes. J Clin Endocrinol Metab 56: 393-396

5. Khokher MA, Taylor AM, Dandona P (1986) Similarities between the insulin-like stimulatory effect of human IgG and NSILP. Diabetes Research (in press)

6. Lowry OH, Roseborough WJ, Farr AL, Randall RJ (1951) Protein measurement with the Folin phenol reagent. J Biol Chem 193: 265-275

7. Rodbell M (1964) Metabolism of isolated fat cells. 1. Effects of hormone on glucose metabolism and lipolysis. J Biol Chem 239: 375-380

8. Moody AJ, Stan MA, Stan M, Gliemann J (1974) A simple free fat cell bioassay of insulin. Horm Metab Res 6:12-16

9. Coulston LG, Dandona P (1980) Insulin like effect of zinc on rat adipocytes. Diabetes 29:665-667

10. Khokher MA, Dandona P (1985) Stimulatory effect of immunoglobulin on glucose oxidation and glucose transport by adipocytes. Br J Exper Pathol 66: 129-135

11. Spencer GSG, Taylor AM (1978) A rapid simplified bioassay for somatomedin. J Endocrin 78: 83-88

12. Taylor AM, Khokher MA, Dandona P (1983) Biguanides inhibit somatomedin action in vitro. In: Spencer $G$ (ed) Insulin like growth factors/somatomedins. Proceedings of an International Symposium, Nairobi, Kenya. Walter de Gruyter, Berlin, pp 619628

13. Mueli C, Zapf J, Froesch ER (1978) NSILA carrier protein abolishes the action of non-suppressible insulin-like activity (NSILAS) on perfused rat heart. Diabetologia 14: 255-259

14. Phillips LS, Bajaj VR, Fusco AC, Matheson CK (1983) Nutrition and somatomedin XI. Studies of somatomedin inhibitors in rats with streptozotocin-induced diabetes. Diabetes 32: 1117-1125

15. Vallance-Owen J, Dennes J, Campbell DA (1958) Insulin antagonism in plasma of diabetic patients and normal subjects. Lancet 2 : 336-338

16. Vallance-Owen J, Bajaj JS (1975) Synalbumin insulin antagonism. In: Vallance-Owen $\mathbf{J}(\mathrm{ed})$ Diabetes. Its physiological and biochemical basis. MTP Press, Lancaster, UK, pp 171-202

Received: 29 November 1985

and in revised form: 3 April 1986

\section{Dr. P. Dandona}

Director of Metabolic Unit and Physician

in Charge of Diabetic Service

Department of Chemical Pathology and Human Metabolism

Royal Free Hospital

Pond Street

London NW3 $2 Q \mathrm{QG}$

UK 